\title{
AN ASOLECTIN ADSORBED SUBSTRATE FOR PROACCELERIN ASSAY
}

\author{
By ARTHUR J. SEAMAN 1 AND PAUL A. OWREN \\ (From the Department of Medicine, Oslo University Hospital, Rikshospitalet, Oslo, Norway)
}

(Submitted for publication August 8, 1955 ; accepted August 31, 1955)

In this report, evidence is presented that asolectin, a commercially available soybean lecithin, is capable under controlled conditions of specifically binding and removing proaccelerin from human plasma. To our knowledge no other selective binding agent or adsorbent of proaccelerin has been reported.

\section{MATERIALS}

Asolectin (commercially available from Associated Concentrates, Inc., 57-01 32nd Avenue, Woodside, New York) Lot Number 2085 was used in this investigation. Fifty mg. per ml. was suspended in distilled water with a Potter homogenizer in the amounts needed immediately prior to use.

Barium sulfate (Baker) analytical grade.

Adsorbed ox plasma. Ox blood freshly collected in one-tenth volume of 2.5 per cent potassium oxalate was centrifuged for 45 minutes at $2500 \mathrm{rpm}\left(2^{\circ}\right.$ C.). The plasma was siphoned off and passed first through a 20 per cent asbestos, then through a 50 per cent asbestos filter by a technique previously reported (1).

Russell viper venom (Stypven, Burroughs Wellcome and Company, London, England) was diluted 1:40,000 in a 1:30 suspension of cephalin in veronal buffer as described by Hjort, Rapaport, and Owren (2), as was the technique for preparation of :

Prothrombin free ox plasma.

Normal human plasma was prepared from the blood of healthy persons. Following venipuncture with a 16 gauge needle, the first $5 \mathrm{ml}$. of blood was collected separately and discarded. The desired quantity of blood was then collected by gravity flow in a second glass bottle containing a quantity of $0.1 \mathrm{M}$ sodium citrate solution equal to one-tenth the final volume, or when oxalated blood was necessarily used, into one-tenth volume of 2.5 per cent potassium oxalate solution. In either case, the freshly collected blood was centrifuged at $2500 \mathrm{rpm}$ and $2^{\circ} \mathrm{C}$. for 45 minutes. The plasma was transferred to another container with a Pasteur pipette and glass-activated by stirring for 5 minutes with one-eighth volume of fine quartz glass powder (particle size less than 0.07 mm.) by the technique of Rapaport, Aas, and Owren (3). Following centrifugation for 15 minutes at 2500

\footnotetext{
1 Fulbright Research Scholar in Norway, 1954-1955. Present address: Division of Experimental Medicine, University of Oregon Medical School, Portland, Ore.
}

rpm and $2^{\circ} \mathrm{C}$. to remove the glass powder, 20-ml. aliquots of the activated plasma were transferred to glass bottles and stored at minus $20^{\circ} \mathrm{C}$. until they were thawed just prior to use.

Citrated, proconvertin deficient plasma was prepared from the blood of a patient with a congenital deficiency of this factor. Studies of the coagulation characteristics of this patient's plasma have been reported previously (4). Collection and processing were as described for citrated normal plasma. Aliquots kept at minus $20^{\circ} \mathrm{C}$. were thawed just before use.

Citrated, proaccelerin deficient plasma was prepared in a similar manner from the blood of a patient with parahemophilia. The clotting characteristics of this patient's blood plasma have been reported in detail elsewhere (5).

Diluting fluid I was prepared as follows:

Sodium citrate $0.1 \mathrm{M}$ solution $\quad 200 \mathrm{ml}$.

Sodium chloride 0.9 per cent solution q. s. $1200 \mathrm{ml}$.

Diluting fluid $I I$ was made by mixing :

Sodium citrate $25.66 \mathrm{mM}$ solution $\quad 200 \mathrm{ml}$.

Veronal buffer $\quad 200 \mathrm{ml}$

Sodium chloride 0.9 per cent solution q. s. $1000 \mathrm{ml}$.

Veronal buffer (pH 7.35, ionic strength 0.154 ) was prepared as previously described (2).

Buffer saline was prepared as follows:

Veronal buffer

$100 \mathrm{ml}$

Sodium chloride 0.9 per cent solution q. s. $1000 \mathrm{ml}$.

Calcium chloride aqueous solutions were prepared with the molarities indicated in each test system.

Saline extract human brain thromboplastin was prepared as described previously (6).

Thrombin: 1000 units of Hemoclaudan Adrenon Leo (Lövens Kemiske Fabrik, Köbenhavn) were dissolved in $10 \mathrm{ml}$. veronal buffer. Further dilutions were made with buffer saline to the extent noted in the text.

\section{ASSAY SYSTEMS}

All incubations and tests were performed at $37^{\circ} \mathrm{C}$. in duplicate.

Fibrinogen reactivity:

Citrated control or test plasma, undiluted $0.2 \mathrm{ml}$. Buffer saline

$0.2 \mathrm{ml}$.

Incubate 3 minutes. Time from addition of :

Thrombin (1:15 in buffer saline)

Thromboplastin time [Quick (7)]:

Citrated control or test plasma, undiluted $0.2 \mathrm{ml}$ Thromboplastin

$0.2 \mathrm{ml}$.

Incubate 3 minutes. Time from addition of :

Calcium chloride $25 \mathrm{mM}$ solution 
Proaccelerin assay:

Test plasma (1: 10 in diluting fluid II) $0.2 \mathrm{ml}$.

Parahemophilia plasma $0.2 \mathrm{ml}$.

Thromboplastin $0.2 \mathrm{ml}$.

Incubate 3 minutes. Time from addition of :

Calcium chloride $30 \mathrm{mM}$ solution

$0.2 \mathrm{ml}$.

Proconvertin assay:

Test plasma (1:10 in diluting fluid II) $0.2 \mathrm{ml}$.

Plasma congenitally deficient in proconvertin $0.2 \mathrm{ml}$.

Adsorbed ox plasma $0.2 \mathrm{ml}$.

Thromboplastin $0.2 \mathrm{ml}$.

Incubate 3 minutes. Time from addition of :

Calcium chloride $35 \mathrm{mM}$ solution

$0.2 \mathrm{ml}$.

Prothrombin assay: [method of $\mathrm{Hjort}$, Rapaport, and Owren (2)]

Test plasma (diluted 1: 5 in diluting fluid I; then $1: 10$ in diluting fluid II; final dilution, therefore, $1: 50$ )

Russell viper venom ( $1: 40,000$ in suspension of cephalin $1: 30$ in veronal buffer) $\quad 0.2 \mathrm{ml}$.

Prothrombin free ox plasma $\quad 0.2 \mathrm{ml}$.

Incubate 3 minutes. Time from addition of :

Calcium chloride $30 \mathrm{mM}$ solution

Anti-thromboplastin detection:

Test plasma, undiluted

Citrated, platelet poor, glass-activated normal plasma, undiluted

Adsorbed ox plasma

Thromboplastin

Incubate 3 minutes. Time from addition of :

Calcium chloride $30 \mathrm{mM}$ solution

$0.2 \mathrm{ml}$.

$0.2 \mathrm{ml}$.

$0.2 \mathrm{ml}$

$0.2 \mathrm{ml}$.

$0.2 \mathrm{ml}$

$0.2 \mathrm{ml}$.

PREPARATION OF PROACCELERIN DEFICIENT PLASMA

FROM NORMAL PLASMA BY ASOLECTIN BINDING AND SEPARATION

To citrated, platelet poor, glass-activated, normal plasma, asolectin homogenized in distilled water was added in the amount of $25 \mathrm{mg}$. of asolectin for each $\mathrm{ml}$. of citrated plasma. Sufficient additional distilled water was then added until the original volume of citrated plasma equalled onesixth the final diluted volume. The glass container was swirled to disperse the asolectin suspension throughout the mixture, covered with Parafilm, and placed in a water bath at $37^{\circ} \mathrm{C}$. for 2 hours. After this period, the dilute plasmaasolectin suspension was transferred to lusteroid tubes, capped, and spun in a Spinco preparatory ultracentrifuge at $40,000 \mathrm{rpm}$ for 1 hour $\left(2^{\circ} \mathrm{C}\right.$.). The tubes were removed with utmost care to avoid agitation of the contents. Caps were not removed since the cuff traps a small quantity of the original suspension. Instead, the central screw plug was removed (again without agitation of the tubes' contents) and a lumbar puncture needle fastened to a 20-ml. Luer-Lok syringe was carefully introduced to a point just above the bottom of the tube on the side opposite the sedimented asolectin. The clear dilute plasma was slowly aspirated until the thin floating surface layer of lipids approached the needle tip. Aspiration was then discontinued and the syringe contents transferred to a graduated cylinder where the clear dilute plasma from all tubes was pooled, measured, and transferred to a glass vacuum flask. The flask's contents were shell-frozen by spinning in a bath of methyl alcohol and carbon dioxide snow. Lyophilization was carried out. When dry, the plasma was reconstituted with distilled water equal to one-sixth the volume of the material transferred to the lyophilizing flask before drying. Correction of the $\mathrm{pH}$ to 7.3 was made by adding $0.5 \mathrm{~N} \mathrm{HCl}$ dropwise with stirring. Multiple lyophilized samples were reconstituted simultaneously, pooled so that a single reference curve would serve for all, frozen and stored in $1-\mathrm{ml}$. aliquots at minus $20^{\circ} \mathrm{C}$.

The assay results in Table $I$ are representative for such reconstituted plasma :

It is seen that proaccelerin was almost completely removed, prothrombin concentration was slightly reduced, proconvertin activity less so. Fibrinogen reactivity was good. Anti-thromboplastic activity was not demonstrated.

The control plasma, without asolectin, was similarly diluted 1:6 with distilled water, alkalinized to $\mathrm{pH} 9.1$ with $0.5 \mathrm{~N} \mathrm{NaOH}$, and incubated 150 minutes at $37^{\circ} \mathrm{C}$. It was then centrifuged at $40,000 \mathrm{rpm}$ for 60 minutes ( $2^{\circ} \mathrm{C}$.), shell frozen, lyophilized, and reconstituted in distilled water equal to one-sixth the total dilute volume. The $\mathrm{pH}$ was corrected to 7.3 with $0.5 \mathrm{~N} \mathrm{HCl}$ added dropwise. No comparable loss of proaccelerin in the reconstituted control plasma occurred as judged by its Quick thromboplastin time of 20.9 and 21.0 seconds in contrast to $75.0,74.6$ seconds for the asolectin adsorbed plasma similarly reconstituted.

It should also be noted that the reconstituted lyophilized asolectin adsorbed plasma was tested undiluted in the anti-thromboplastin detection test. This would actually represent a six-fold increase in concentration of any such substances in the clear supernate since reconstitution was effected with one-sixth the total dilute volume. Actually, no 
TABLE I

The following assay results are representative for reconstituted asolectin adsorbed plasma

\begin{tabular}{|c|c|c|c|c|c|c|}
\hline \multirow[b]{2}{*}{$\begin{array}{l}\text { Thromboplastin time (Quick) } \\
\text { Prothrombin } \\
\text { Proaccelerin } \\
\text { Proconvertin } \\
\text { Fibrinogen reactivity } \\
\text { Anti-thromboplastin detection }\end{array}$} & \multicolumn{2}{|c|}{$\begin{array}{l}\text { Reconstituted asolectin } \\
\text { adsorbed plasma } \\
\text { time in seconds }\end{array}$} & \multirow{2}{*}{$\begin{array}{r}\text { Per } \\
\text { cent }\end{array}$} & \multicolumn{2}{|c|}{$\begin{array}{l}\text { Unadsorbed plasma } \\
\text { same source* } \\
\text { time in seconds }\end{array}$} & \multirow{2}{*}{$\begin{array}{r}\begin{array}{r}\text { Per } \\
\text { cent }\end{array} \\
72 \\
100 \\
100\end{array}$} \\
\hline & $\begin{array}{l}75.0, \\
39.8, \\
81.6, \\
23.6, \\
22.1 \\
12.1\end{array}$ & $\begin{array}{l}74.6 \\
39.2 \\
83.3 \\
23.2 \\
22.9 \\
11.7\end{array}$ & & $\begin{array}{l}11.9, \\
32.8, \\
23.7 \\
22.6 \\
20.7 \\
11.9\end{array}$ & $\begin{array}{l}11.6^{*} \\
32.3 \\
23.2 \\
19.9 \\
19.9 \\
12.0\end{array}$ & \\
\hline
\end{tabular}

* Same plasma diluted 1:6 with distilled water, $\mathrm{pH}$ adjusted to 9.1 with $0.5 \mathrm{~N} \mathrm{NaOH}$, incubated 150 minutes at $37^{\circ} \mathrm{C}$., centrifuged 60 minutes at $40,000 \mathrm{rpm}$, shell frozen and lyophilized gave Quick thromboplastin times after reconstitution with distilled water equal to one-sixth of the total dilute volume and correction of $\mathrm{pH}$ to 7.3 with $0.5 \mathrm{~N} \mathrm{HCl}$ of 20.9 seconds and 21.0 seconds on duplicate samples.

anti-thromboplastins were demonstrable even under these conditions.

Evidence that asolectin specifically binds proaccelerin rather than destroys it is seen in the following experiment : $25 \mathrm{mg}$. of asolectin per ml. of citrated normal plasma (platelet poor, glass-activated) was suspended directly in the plasma with a Potter homogenizer. This mixture was then transferred to a glass tube, covered with Parafilm and incubated in a water bath at $37^{\circ} \mathrm{C}$. Periodically, samples were taken for testing in the following system:

\section{Diluting fluid II}

Thromboplastin

$0.2 \mathrm{ml}$

Homogenized asolectin in normal plasma (citrated, platelet poor, glass-activated) $25 \mathrm{mg}$. per $\mathrm{ml}$.

Incubate 3 minutes. Time from addition of: Calcium chloride $30 \mathrm{mM}$ solution $0.2 \mathrm{ml}$.

$0.2 \mathrm{ml}$

$\begin{array}{cr}\begin{array}{c}\text { Incubation time } \\ \text { in minutes } \\ 0\end{array} & \text { Time } \\ & 38.6,39.2 \\ & \\ & \\ 15 & 38.8,39.4 \\ 30 & 40.4,38.9 \\ 45 & 40.8,39.2 \\ 60 & 40.6,39.8 \\ 75 & 41.7,39.1 \\ 90 & 41.2,39.0 \\ 105 & 42.3,39.5 \\ 120 & 41.6,40.7\end{array}$

Plasma incubated with asolectin $25 \mathrm{mg}$. per $\mathrm{ml}$. in fine suspension for 120 minutes, diluted $1: 6$ with distilled water, spun $40,000 \mathrm{rpm}$ for 60 minutes to remove asolectin, lyophilized and reconstituted in original volume gave 88.0 and 87.6 seconds in the same system.

We interpret these results to mean that no considerable deterioration of proaccelerin occurs on incubation with $25 \mathrm{mg}$. per $\mathrm{ml}$. asolectin for two hours at $37^{\circ} \mathrm{C}$. We have previously demonstrated that dilution, alkalinization, incubation, centrifugation, lyophilization, neutralization, and reconstitution of normal plasma in the initial volume does not result in comparable loss of proaccelerin activity. The marked depletion of proaccelerin that occurs when asolectin is spun out reflects the specific binding and co-sedimentation of a proaccelerin-asolectin complex, in our opinion. Whether this binding is physical or chemical cannot be stated with certainty at this time. Further investigation along this line is planned as is further consideration of the inhibitory effect of asolectin on the thromboplastin time and whether this is related to the asolectin-proaccelerin complex (i.e., an anti-proaccelerin effect). Reutilizing once used asolectin sediment in equal concentration to adsorb a second equal portion of dilute normal plasma by the identical technique results in marked reduction of its ability to remove proaccelerin. $\mathrm{Re}$ constituted plasma adsorbed with once previously used asolectin gave proaccelerin reduction to only 60 per cent of original activity instead of 0 per cent as in the first adsorption.

The following curves (Figure 1) compare the proaccelerin assay of known dilutions of normal citrated plasma in diluting fluid I when parahemophilia plasma was the substrate (dotted line) and when reconstituted asolectin adsorbed plasma was the substrate (solid line).

Demonstration of the mutual inability of para- 


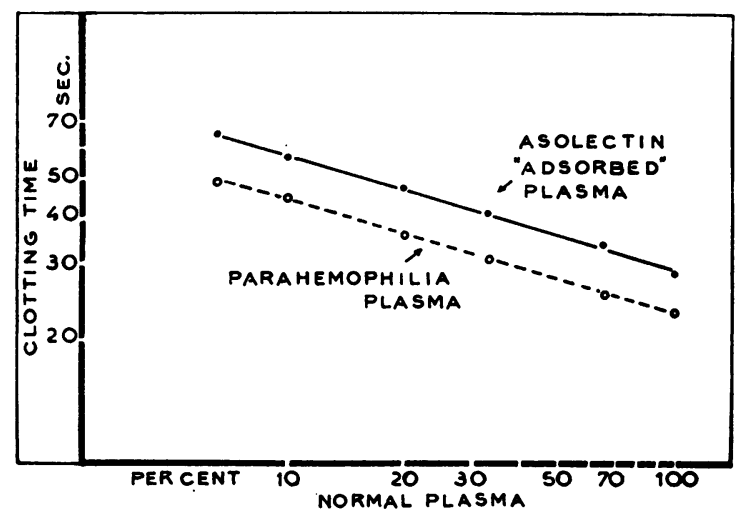

Fig. 1. Comparison of Parahemophilia Plasma and Asolectin Adsorbed Plasma as Substrate for Proaccelerin Assay

hemophilia plasma and reconstituted asolectin adsorbed plasma to correct one another is shown in the following results :

Parahemophilia plasma substrate Reconstituted asolectin adsorbed plasma (1: 10 in diluting fluid II)

Thromboplastin

Calcium chloride $30 \mathrm{mM}$ solution

\section{$0.2 \mathrm{ml}$.}

$0.2 \mathrm{ml}$.

$0.2 \mathrm{ml}$.

$0.2 \mathrm{ml}$.

81.6, 83.3 seconds

(equals 0 per cent proaccelerin)

Reconstituted asolectin adsorbed plasma substrate

Parahemophilia plasma (1:10 in diluting fluid II)

Thromboplastin

Calcium chloride $30 \mathrm{mM}$ solution

$0.2 \mathrm{ml}$.

$0.2 \mathrm{ml}$.

$0.2 \mathrm{ml}$.

$0.2 \mathrm{ml}$.

$87.6,88.4$ seconds (equals 0 per cent proaccelerin)

To determine if the results of the assay (Figure 1) were solely a reflection of the proaccelerin content and to exclude prothrombin and procon- vertin activity as possible causes of the variations, the following experiment was designed:

Freshly prepared, oxalated, platelet poor, glassactivated, normal plasma was divided into two portions. One was mixed with $75 \mathrm{mg}$. of barium sulfate per ml. of oxalated plasma for 5 minutes at $20^{\circ} \mathrm{C}$., then separated by centrifugation for 25 minutes at $2500 \mathrm{rpm}\left(2^{\circ} \mathrm{C}\right.$. $)$. Since some proaccelerin is non-specifically removed during barium sulfate adsorption, the unadsorbed oxalated plasma was diluted with buffer saline solution until its proaccelerin activity in correcting parahemophilia plasma substrate equalled that of the barium sulfate adsorbed plasma against the same substrate. The adjusted unadsorbed plasma mixture that accomplished this was 90 per cent oxalated unadsorbed plasma and 10 per cent buffer saline. Varying mixtures of barium sulfate adsorbed and unadsorbed plasma were tested in the proaccelerin assay system using asolectin adsorbed plasma as substrate. If this substrate is corrected by the proaccelerin content of the mixture and is insensitive to the varying prothrombin and proconvertin content, one would expect the same correction by all the mixtures. In Table II it can be seen that this was substantially the case. Test system is as described in section headed "ASSAY SYSTEMS" for proaccelerin with the difference that asolectin adsorbed reconstituted plasma is substituted as the substrate plasma for parahemophilia plasma.

\section{COMMENT}

Asolectin is not completely separable by centrifugation from undiluted plasma and, indeed, rises to the surface. Reduction of specific gravity and ionic strength by dilution with distilled water seems necessary for its complete separation by

TABLE II

Effect of varying prothrombin and proconvertin content on proaccelerin content in mixtures of BaSO, adsorbed plasma and unadsorbed plasma

\begin{tabular}{|c|c|c|c|c|c|c|}
\hline \multicolumn{7}{|l|}{ Plasma mixtures } \\
\hline $\begin{array}{l}\text { Oxalated } \mathrm{BaSO}_{4} \text { adsorbed plasma }(\%) \\
\text { Unadsorbed plasma }(\%)\end{array}$ & $\begin{array}{r}100 \\
0 \\
\end{array}$ & $\begin{array}{l}80 \\
20\end{array}$ & $\begin{array}{l}60 \\
40 \\
\end{array}$ & $\begin{array}{l}40 \\
60\end{array}$ & $\begin{array}{l}20 \\
80\end{array}$ & $\begin{aligned} 0 \\
100\end{aligned}$ \\
\hline $\begin{array}{l}\text { Prothrombin (\%) } \\
\text { Proconvertin (\%) } \\
\text { Proaccelerin (\%) }\end{array}$ & $\begin{array}{l}\mathbf{0} \\
\mathbf{0} \\
\mathrm{C}\end{array}$ & $\begin{array}{l}20 \\
20 \\
\text { nt in al }\end{array}$ & $\begin{array}{c}40 \\
40 \\
\text { mixtu }\end{array}$ & $\begin{array}{l}60 \\
60\end{array}$ & $\begin{array}{l}80 \\
80\end{array}$ & $\begin{array}{l}100 \\
100\end{array}$ \\
\hline $\left.\begin{array}{l}\text { Time in seconds } \\
\text { Duplicates }\end{array}\right\}$ & $\begin{array}{l}33.0 \\
32.6\end{array}$ & $\begin{array}{l}35.0 \\
34.8\end{array}$ & & & $\begin{array}{l}33.6 \\
33.0\end{array}$ & $\begin{array}{l}32.2 \\
33.6\end{array}$ \\
\hline
\end{tabular}


sedimentation on centrifugation. The adsorbed dilute plasma can then be lyophilized and reconstituted with an amount of distilled water equal to the original plasma volume.

Twenty-five mg. of asolectin per $\mathrm{ml}$. of citrated plasma was determined to be the optimum amount and 120 minutes at $37^{\circ} \mathrm{C}$. the optimum incubation period. Lesser amounts of asolectin or shorter periods of incubation resulted in less complete adsorption of proaccelerin. Greater concentrations of asolectin resulted in progressively larger adsorption of prothrombin in addition to proaccelerin and, with still greater concentrations, in considerable loss of fibrinogen reactivity.

One additional interesting thing becomes apparent from inspection of the systematic assay data (not presented here) when larger quantities of asolectin than recommended in this paper (for adsorption of proaccelerin) are used. Prothrombin adsorption becomes almost complete while proconvertin activity is only slightly diminished. Further examination of this phenomenon is discussed in another communication (8).

Paralleling their remarkable similarity of behavior in some other respects, we have found that cephalin derived from human brain by a modification of the technique of Milstone (9) also behaved as a proaccelerin adsorbent when substituted for asolectin in the technique outlined in this paper. Because asolectin is commercially available, whereas the preparation of cephalin from human brain is tedious, the technique using the former alone is reported in detail here.

It is interesting to speculate that possibly the similar lipid material of thrombocytes may be responsible for their demonstrated behavior as an adsorbent of proaccelerin (10).

\section{SUM MARY}

Evidence is presented that asolectin in an amount of $25 \mathrm{mg}$. per $\mathrm{ml}$. of the original citrated plasma volume, suspended in normal plasma diluted $1: 6$ with distilled water, incubated $120 \mathrm{~min}$ utes at $37^{\circ} \mathrm{C}$., and removed by centrifugation at
$40,000 \mathrm{rpm}$ for 1 hour, is capable of specifically binding and removing the proaccelerin of the normal plasma. The adsorbed dilute plasma was shell frozen, lyophilized, and reconstituted with one-sixth volume of distilled water. Control normal plasma similarly treated with the omission of asolectin exposure showed no comparable loss of proaccelerin.

Such asolectin adsorbed reconstituted plasma was comparable in its behavior as a substrate plasma for a proaccelerin activity assay system to the naturally occurring parahemophilia plasma used as a substrate plasma in the same system.

Evidence of the specificity of the asolectin adsorbed plasma substrate response for proaccelerin activity of the test samples is presented.

\section{REFERENCES}

1. Owren, P. A., and Aas, K., The control of Dicumarol therapy and the quantitative determination of prothrombin and proconvertin. Scandinav. J. Clin. \& Lab. Invest., 1951, 3, 201.

2. Hjort, P., Rapaport, S. I., and Owren, P. A., A simple, specific one-stage prothrombin assay using Russell's viper venom in "cephalin" suspension. J. Lab. \& Clin. Med., 1955, 46, 89.

3. Rapaport, S. I., Aas, K., and Owren, P. A., The effect of glass upon the activity of the various plasma clotting factors. J. Clin. Invest., 1955, 34, 9.

4. Owren, P. A., Prothrombin and accessory factors. Clinical significance. Am. J. Med., 1953, 14, 201.

5. Owren, P. A., The Coagulation of Blood; Investigations on a New Clotting Factor. Oslo, J. C. Gundersen, 1947.

6. Owren, P. A., A quantitative one-stage method for the assay of prothrombin. Scandinav. J. Clin. \& Lab. Invest., 1949, 1, 81.

7. Quick, A. J., The prothrombin in hemophilia and in obstructive jaundice. J. Biol. Chem., 1935, 109, Ixxiii.

8. Seaman, A. J., and Owren, P. A., Asolectin separation of prothrombin from proconvertin. J. Clin. Invest., To be published.

9. Milstone, J. H., The problem of the lipid thromboplastins. Yale J. Biol. \& Med., 1950, 22, 675.

10. Hjort, P., Rapaport, S. I., and Owren, P. A., Evidence that platelet accelerator (platelet factor 1) is identical to proaccelerin and adsorbed from plasma. Blood, In press. 